\title{
Pemberdayaan Limbah Serabut Kelapa Menjadi Pobuke Berbasis Geometri Untuk Menaggulangi Tingkat Pengagguran Di Desa Senyiur
}

\author{
Rifaatul Mahmudah $^{1}$, Abdullah $^{2}$, Hadiatul Rodiyah $^{3}$, Susilawati $^{4}$ \\ rifadikdas@gmail.com ${ }^{1}, \underline{\text { abd31d66@gmail.com }{ }^{2},}$ hadiatulrodiyah3@gmail.com ${ }^{3}$, \\ mb.susilawati@gmail.com ${ }^{4}$ \\ Pendidikan Sekolah Dasar (PGSD), Fakultas Ilmu Pendidikan (FIP), \\ Universitas Hamzanwadi ${ }^{1}$
}

DOI: 10.29408/ab.v1i1.2409

\begin{abstract}
Abstrak: Desa senyiur merupakan salah satu daftar perdesaan yang menjadi pusat perhatian pemerintah. Perdesaan tersebut membutuhkan pendampingan untuk mengelola potensi daerah mereka melihat banyaknya pengangguran. Faktor pendorong peningkatan Pengangguran karena tingginya angka kemiskinan yang menyebabkan banyak yang tidak menikmati bangku sekolah. Dampaknya para pengangguran tidak memiliki skill yang handal. Masyarakat pengangguran terdiri dari anak terlantar/putus sekolah dan ibu rumah tangga yang tidak memiliki hasil tetap. Salah satu pemecahan masalahnya adalah memberdayakan serabut kelapa menjadi barang yang bernilai ekonomis, karena dapat membantu perekonomian masyarakat pengangguran. Target luaran yang hendak dicapai adalah memberdayakan limbah serabut kelapa menjadi POBUKE (Pot Bunga Kekinian) berbasis geometri. Geometri tersebut merupakan software geometri interaktif untuk ketepatan dan simulasi penggunaan, agar mudah memanipulasi dan membuat objek-objek geometris, karena seni secara universal memiliki hubungan geometri yang begitu kompleks. Manfaat penelitian ini tidak lain membantu pemerintah mengurangi tingkat pengangguran serta terciptanya lapangan pekerjaan. Harapanya dapat menumbuh kembangkan jiwa enterpreuner masyarakat pengangguran. Produk ini juga dapat dijadikan sebagai media pembelajaran matematika. Metode dalam kegiatan ini adalah menggunakan metode demonstrasi, ceramah, diskusi, praktik dan obsevase. 1. Metode demonstrasi berbasis ceramah digunakan sebagai simulasi training atau kegiatan pelatihan. 2. Metode diskusi digunakan sebagai komunikasi dua arah yang bersifat terbuka antara para tim peneliti dan pemateri dengan para karyawan. 3. Metode praktik untuk mengimlplementasikan pengetahuan yang sudah didapatkan dari para tim peneliti dan pemateri yang professional dalam bidang kerajinan. 3. Metode observase sebagai evaluasi tingkat pemahaman masyarakat dalam mengimplementasikan simulasi yang sudah diberikan.
\end{abstract}

Kata Kunci : Serabut Kelapa, POBUKE, Geometri dan Pengangguran

\section{PENDAHULUAN}

Tanaman kelapa atau bahasa latinnya Cocos nucivera. L/ terbesar di Indonesia salah satunya ada di daerah Lombok. Lombok merupakan daerah yang terletak di sepanjang garis khatulistiwa, karena Tanaman kelapa yang baik tumbuh di daerah tropis (Aziz, et al: 2018). Buah kelapa dikirim ke jawa tanpa serabut, sehingga serabut menjadi limbah. Serabut yang produktif tersebut tidak diberdayakan melainkan dibakar untuk keperluan memasak dan mencuci piring. Selain itu serabut kelapa dikirim ke jawa dengan harga yang sangat miring. Potensi daerah tersebut sangat bermanfaat dan berniali tinggi, jika diberdayakan ke daerah yang menjadi pusat perhatian pemerintah. Desa Senyiur merupakan salah satu daftar pedesaan di Lombok yang menjadi pusat perhatian pemerintah. Pedesaan tersebut membutuhkan 


\section{ABSYARA: JURNAL PENGABDIAN PADA MASYARAKAT BIDANG PENDIDIKAN, SAINS, DAN TEKNOLOGI}

Vol. 1 No. 1, Juli 2020, Hal. 33-43

pendampingan untuk mengelola potensi daerah mereka melihat banyaknya pengangguran. Tanaman kelapa dijuluki sebagai pohon kehidupan, karena semuanya dapat dimanfaatkan dan bernilai ekonomis tinggi. Mulai dari akar, batang, buah daun dan serabutnya (Warisno, 2003). Tapi kenyataannya sangat jauh berbeda. Kelapa tidak diolah melainkan buah kelapa langsung dikirim ke jawa tanpa serabut akibatnya serabut menumpuk kurang dimanfaatkan. Omset penjualanpun hanya didapatkan satu kali dalam tiga bulan. Melihat peluang pemasaran tersebut maka roda perekonomian terus menurun, sehingga terjadinya peningkatan pengangguran. Faktor pendorong peningkatan pengangguran berdampak terhadap banyaknya pengangguran. Pengangguran terjadi karena masyarakat banyak tidak menikmati bangku sekolah, sehingga tidak memiliki skill yang handal.

Dari permasalahan tersebut peneliti memiliki inisiatif untuk mengajak masyarakat produktif secara ekonomi dengan memberdayakan potensi yang ada. Potensi tersebut yakni limbah serabut yang dijadikan sebagai POBUKE (Pot Bunga Kekinian) berbasis geometri untuk menanggulangi pengangguran. Aturan baku pada geometri dalam pembuatan untuk menghemat waktu serta biaya. Dengan adanya pengetahuan tentang geometri dapat mengurangi kerusakan dan biaya, karena seni secara universal memiliki hubungan geometri yang begitu kompleks. Untuk ketepatan dibantu dengan software geometri interaktif, agar mudah memanipulasi dan membuat objek-objek geometris untuk menghasilkan nilai unsure estetika.

Pengolahan hasil buah kelapa masih bersifat monoton fokus pada pengolahan hasil daging buahnya saja sebagai hasil utama dikelola secara tradisional. Saat ini serabut kelapa potensi ketersediaan tersebut belum dimanfaatkan secara optimal. Berdasarkan data dari esmart school, serabut kelapa merupakan bagian yang cukup besar dari buah kelapa, yaitu 35\% dari berat keseluruhan buah yang terdiri dari serat dan gabus. Setiap butir kelapa mengandung serat 525 gr (75\%dari serabut), sedangkan gabus 175 gr (25\% dari serabut). Dengan produksi buah kelapa Indonesia rata-rata 15,5 milyar butir/tahun. Atau setara dengan 1,8 juta ton serat serabut, dan 3,3 juta ton debu serabut (Agustian, et al., 2003; Allorerung \& Lay, 1998; Anonim, 2000; Nur, et al., 2003; APCC, 2003), maka serabut dirasa cukup banyak yang tersedia

Serabut kelapa pada dasarnya dijual untuk bahan bakar bata dengan harga yang sangat murah untuk satu truk. Beda halnya ketika serabut kelapa diolah dengan harga yang sangat menjanjikan.Potensi kekayaan hasil, pertanian laut dan perkebunan mereka di desa Senyiur kec. Keruak sangat tidak mendapat perhatian pemerintah setempat dalam membantu perkembangan perekonomian mereka, karena tidak adanya sentuhan maupun pendamping secara langsung. Sedangkan jika dilihat dari Sumber Daya Manusianya sangat mendukung untuk diberdayakan limbah serabut kelapa menjadi POBUKE berbasis geometri.

Penduduk masayarakat desa Senyiur yang masih pengangguran belum memiliki wadah dalam mengembangkan bakat mereka dengan mengasah potensi hasil perkebunan mereka menjadi mata pencaharian sebagai penambahan ekonomi. Pemicu utama terjadinya tingkat pengangguran yang semakin tinggi adalah factor ekonomi. Dampaknya masyarakat banyak yang tidak mampu mengenyam pendidikan, menghambat mesyarakat untuk menjadi cerdas dan 


\section{ABSYARA: JURNAL PENGABDIAN PADA MASYARAKAT \\ BIDANG PENDIDIKAN, SAINS, DAN TEKNOLOGI}

Vol. 1 No. 1, Juli 2020, Hal. 33-43

e-ISSN: 2723-6269

kompetitif, sehingga tidak banyak memiliki skill untuk mencari penghasilan. Semakin besar angka pengangguran maka semakin sulit untuk mengatasinya.

Globalisasi dibidang ekonomi menyebabkan krisis terhadap ketimpangan sosial dan pengangguran. Akibatnya terancam kemandirian komunitas local terhadap ekonomi perubahan. Dengan adanya pemberdayaan serabut kelapa akan mampu mengurangi angka tinggi pengangguran.

Serabut kelapa sangat mudah didapatkan dipengusaha kelapa atau pemilik kebun kelapa dibeberapa daerah yang ada di Lombok umumnya. Serabut kelapa terlihat numpuk tidak dimanfaatkan seeperti terlihat dalam gambar sebelumnya. Serabut kelapa juga biasanya dijual murah untuk pembakaran bata atau sebagai bahan bakar masak, karena banyaknya barang tidak sebanding dengan permintaan pasar. Oleh sebab itu peneliti mengajak masyarakat bagaimana memberdayakan dengan sebaik-baiknya potensi tersebut menjadi barang yang bernilai tinggi dikemas menjadi POBUKE (Pot Bunga Kekinian) berbasis geometri. Dimana pembuatan POBUKE (Pot Bunga Kekinian) berbasis geometri yang didampingi oleh para pakar dibidang masing-masing.

Berangkat dari permasalahan tersebut tim PKM -M Universitas Hamzanwadi melihat hal-hal yang yang dapat dimanfaatkan dari limbah serabut kelapa sebagai benda yang mempunyai nilai ketika dapat diolah menjadi benda yang unik dan bernilai jual. Banyak kerajinan yang dapat dihasilkan dari olahan limbah serabut kelapa misalnya keset, sapu,tas, sandaran kursi, kasur dan lain sebagainya. Semuanya dapat dihasilkan dari olahan serabut kelapa. Namun dalam hal ini tim PKM menekankan bahwasannya serabut kelapa akan diolah menjadi produk POBUKE (Pot Bunga Kekinian) berbasis geometri.

POBUKE (Pot Bunga Kekinian) berbasis geometri merupakan produk alternatif sebagai salah satu media tanam ramah lingkungan, dapat menggantikan polibag yang biasanya terbuat dari plastik yang tidak ramah lingkungan. Adapun tujuan penelitian ini adalah memberdayakan atau memanfaatkan serabut di jadikan sebagai POBUKE berbasis geometri, sehingga dapat menumbuh kembangkan jiwa enterpreuner masyarakat pengangguran serta mengetahui prospek produk bernilai ekonomi tinggi.

Banyak manfaat dari pohon kelapa, maka dari itu pohon kelapa sering disebut pohon 1000 (seribu) manfaat. Karena dari ujung akar pohon kelapa, sampai denga ujung daun pohon kelapa bisa dimanfaatkan dengan bebagai macam bentuk dan macam-macam kegunaan. Kelapa adalah pohon serba guna bagi masyarakat tropika. Hampir semua bagiannya dapat dimanfaatkan orang. Akar kelapa menginspirasi penemuan teknologi penyangga bangunan Cakar Ayam (dipakai misalnya pada Bandar Udara Soekarno Hatta) oleh Sedijatmo. Kayu dari batangnya, yang disebut kayu glugu, dipakai orang sebagai kayu dengan mutu menengah, dan dapat dipakai sebagai papan untuk rumah. Daunnya dipakai sebagai atap rumah setelah dikeringkan. Daun muda kelapa, disebut janur, dipakai sebagai bahan anyaman dalam pembuatan ketupat atau berbagai bentuk hiasan yang sangat menarik, terutama oleh masyarakat Jawa dan Bali dalam berbagai upacara, dan menjadi bentuk kerajinan tangan yang berdiri sendiri (seni merangkai 
janur). Tangkai anak daun yang sudah dikeringkan, disebut lidi, dihimpun menjadi satu menjadi sapu (Arifiandi, 2015).

Keuntungan dari penggunaan sabut kelapa yaitu sabut kelapa memiliki sifat tahan lama, sangat ulet, kuat terhadap gesekan, tidak mudah patah, tahan terhadap air, tidak mudah membusuk, tahan terhadap jamur, dan hama serta tidak dihuni oleh rayap dan tikus. Sabut kelapa terdiri dari serat dan gabus yang menghubungkan satu serat dengan serat lainnya yang merupakan bagian berharga dari sabut. Setiap butir kelapa rata-rata mengandung serat 525 gram (75\% dari sabut), dan gabus 175 gram (25\% dari sabut). Maka dari itu sangat banyak keuntungan jika menggunakan sabut kelapa sebagai bahan utama dalam pembuatan kaligrafi (Pristi, 2019)

Manfaat yang dapat diambil dapat mengolah limbah serabut kelapa yang tidak bermanfaat menjadi nilai jual yang tinggi, membantu pemerintah mengurangi tingkat pengangguran serta tidak ada lagi limbah serabut kelapa bertumpukan dan pendapatan ekonmi masyarakat bertambah.

\section{METODE PELAKSANAAN}

\section{Waktu dan tempat}

Kegiatan ini dilaksanakan pada bulan April 2019 di Desa Senyiur Kec. Keruak Kabupaten Lombok Timur.

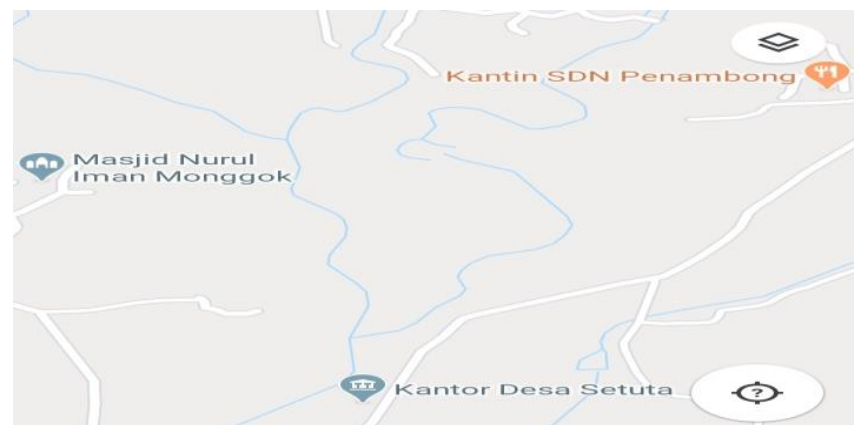

Gambar 1. Peta Wilayah Desa Senyiur, Kec. Keruak, Kabupaten Lombok Timur (Google Maps 2019)

a. Alat dan Bahan

Tabel 1. Alat dan bahan pembuatan Pot Bunga Kekinian (POBUKE)

\begin{tabular}{llll}
\hline \multicolumn{1}{c}{ Keterangan } & Banyaknya & \multicolumn{1}{c}{ Harga Satuan } & \multicolumn{1}{c}{ Total } \\
Biaya pembelian bahan baku & & & \\
\hline Serabut Kelapa & 20 karung & Rp 10,000 & Rp 200,000 \\
Lem rajawali & 5 bungkus & Rp 9,000 & Rp 45,000 \\
Lem tembak & 10 buah & Rp 35.000 & Rp. 350.000
\end{tabular}




\begin{tabular}{|c|c|c|c|}
\hline absyara & \multicolumn{3}{|c|}{$\begin{array}{r}\text { ABSYARA: JURNAL PENGABDIAN PADA MASYARAKAT } \\
\text { BIDANG PENDIDIKAN, SAINS, DAN TEKNOLOGI } \\
\text { Vol. } 1 \text { No. } 1, \text { Juli } 2020, \text { Hal. } 33-43\end{array}$} \\
\hline Isi refill lem tembak & 10 lusin & Rp 1.000 & Rp 60.000 \\
\hline Kawat jarring & 15 rol & $\operatorname{Rp} 98.500$ & Rp 492.500 \\
\hline Gunting besi & 8 buah & Rp 175.000 & Rp. 1.400 .000 \\
\hline Meteran & 8 buah & Rp 90.500 & Rp. 724.000 \\
\hline \multicolumn{4}{|l|}{ Perlengkapan } \\
\hline Cutter & 4 Buah & $\operatorname{Rp} 12,500$ & Rp 50,000 \\
\hline Penggaris Besi & 8 Buah & Rp 15,000 & Rp 120,000 \\
\hline kertas HVS & $1 \mathrm{Rim}$ & Rp 35,000 & $\operatorname{Rp} 35,000$ \\
\hline Pensil & 1 Pack & Rp 29,000 & Rp 29,000 \\
\hline Spidol & 10 buah & Rp 5,000 & Rp 50,000 \\
\hline Bulpent & 1 Pack & $\operatorname{Rp} 37,000$ & $\operatorname{Rp} 37,000$ \\
\hline Pembuatan Brosur & 100 & $\operatorname{Rp} 250$ & $\operatorname{Rp} 25,000$ \\
\hline Pembuatan Katalog & 3 paket & Rp 25,000 & $\operatorname{Rp} 75,000$ \\
\hline Banner 1mx2m & 1 buah & Rp 100,000 & Rp 100,000 \\
\hline TOTAL & & & Rp3.792.500 \\
\hline
\end{tabular}

b. Metode Kegiatan

Metode dalam kegiatan ini adalah dengan menggunakan metode demonstrasi, ceramah, diskusi, praktik dan obsevase yang dilakukan oleh ketua dan anggota berdasarkan kepakaran. Adapun uraian metode pelaksanaan kegiatan ini yaitu, sebagai berikut:

1. Metode demonstrasi

Memberikan training atau pelatihan menggunakan ceramah terhadap pengenalan dan pengaplikasian software geometri interaktif untuk proses pembuatan Pot Bunga Kekinian (POBUKE) berbasis geometri dari limbah serabut kelapa. Software tersebut bertujuan memudahkan karyawan memanipulasi, membuat objek-objek geometris secara sistematis, dan dapat menigkatkan produktivitas serta kreatifitas masyarakat yang mengandung nilai estetika dalam ketepatan dan kecepatan. Sehingga dapat menghemat waktu dan biaya.

2. Metode diskusi

Diskusi digunakan sebagai komunikasi dua arah yang bersifat terbuka, baik antara pemateri dengan masyarakat pengangguran atau para calon karyawan yang ditraining seputar software geometri interaktif dalam proses pembuatan pot bunga kekinian (POBUKE)berbasis geometri dari limbah serabut kelapa. Tujuannya tidak lain untuk melihat sejauh mana tingkat pemahaman masyarakat terhadap demonstrasi yang telah diberikan.

3. Metode praktik

Praktik bertujuan untuk melihat langsung. Bagaimana masyarakat mengimplementasikan/ mengaplikasikan pengetahuan yang sudah didapatkan dari pemateri yang berkaitan dengan software geometri interaktif. Dimana masyarakat langsung menjalankan proses pembuatan Pot Bunga Kekinian (POBUKE) berbasis geometri dari limbah serabut kelapa tersebut.

4. Metode observase 
Sebagai evaluasi tingkat pemahaman mereka dalam memanipulasi dan membuat objekobjek geometris secara sistematis dalam proses pembuatan Pot Bunga Kekinian (POBUKE) berbasis geometri dari limbah serabut kelapa tersebut, sehingga dapat menigkatkan produktivitas serta kreatifitas yang mengandung unsure estetika.

\section{Prosedur Pelaksanaan}

1. Tahap Persiapan Produksi

Sebelum masuk dalam tahap produksi terdapat beberapa persiapan-persiapan yang harus dilakukan untuk menciptakan sistem produksi yang efektif dan efisien serta mampu mempertahankan mutu produk secara optimal. Persiapan-persiapan tersebut antara lain:

a. Survey lokasi

Survey lokasi yang akan dijadikan tempat pembuatan Pot Bunga Kekinian (POBUKE) berbasis geometri. Rencana lokasi langsung disalah satu rumah warga dengan berbagai pertimbangan.

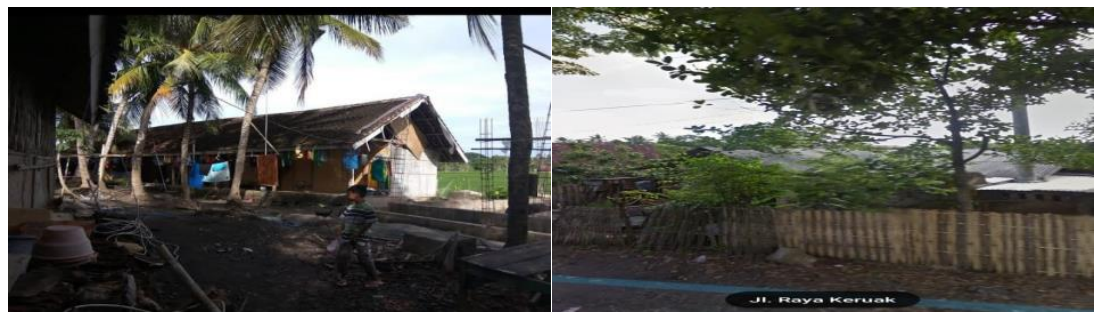

Gambar 2. keadaan desa Senyiur kec. Keruak

b. Survey serabut kelapa

Survey serabut kelapa bertujuan untuk mencari serabut yang memiliki kualitas serabut terbagus, termurah serta dapat mensupplai bahan baku yang berkelanjutan. Dari survey ini juga sekaligus mencari harga yang paling murah dan mudah dalam bekerjasama terhadap tempat-tempat yang potensial untuk pemasaran hasil produksi.

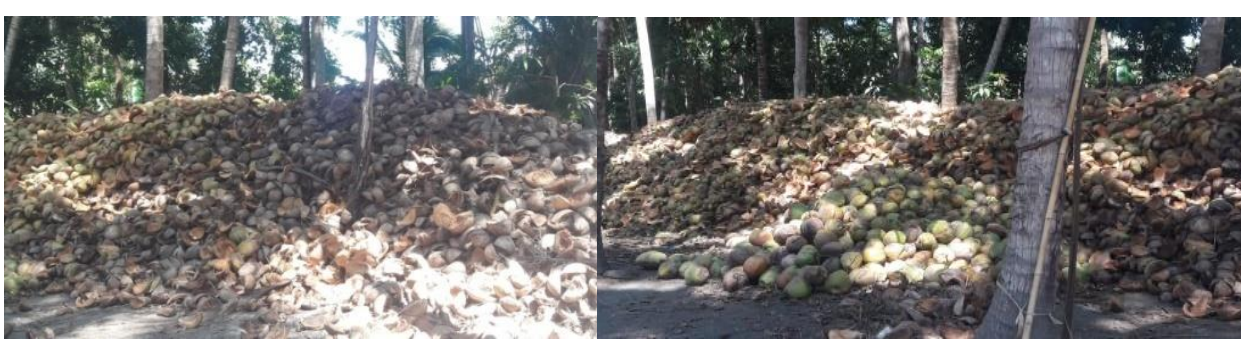

Gambar 3. keadaan serabut kelapa di gudang yang tidak dimanfaatkan

c. Media pemasaran produksi

Media pemasaran akan dilakukan secara offline dan online. Secara offline melalui pemesanan langsung ke toko dan dipromosikan ke toko-toko. Secara online dengan 
memanfaatkan beberapa aplikasi media sosial seperti; whatsApp, Facebook, messenger, Line, Twitter, serta aplikasi terupdet sekalipun.

d. Pembelian bahan-bahan produksi

Pada tahap ini sudah dilakukan pembelian bahan baku ditempat serabut kelapa yang sudah disurvey dan menjadi mitra kerjasama. Selain itu, tahap ini dilakukan pula pembelian alat penunjang pembuatan kerajinan.

e. Pembuatan desain

Pembuatan desain produk berdasarkan permintaan pasar dan desaint yang memang sudah dirancang yang mengintegrasikan geometri matematika dalam pembuatan dasar pola kerajinan tersebut.

2. Tahap Pelaksanaan Kegiatan

a. Produksi

Untuk desain pembuatan dan produksi dikerjakan langsung di lokasi yang telah ditetapkan dengan berbagai pertimbangan. Desain pembuatan produksi berdasarkan minat pasar dan pemesanan langsung dari konsumen.

b. Publikasi dan Pemasaran Produk

Publikasi dan pemasaran produk dilakukan secara online dan offline, karena cara ini dirasa sangat efektif. Produksi dan pemesanan akan disediakn khusus buku katalog yang sudah didesain dengan bantuan dasar geometri dalam pembentukan beberapa pola disetiap produk. Untuk menghindari overload produk yang tidak belum tentu diminati konsumen. Selain itu akan dipersiapkan katalog secara online juga berdasarkan minat konsumen memilih model.

\section{HASIL DAN PEMBAHASAN \\ HASIL}

Setelah melaksanakan tahap pertama, yakni tahapan persiapan produksi, maka dilanjutkan ketahap ke dua, yakni pelaksanaan kegiatan. Berdasarkan pelaksanaan pelatihan dalam pembuatan POBUKE (Pot Bunga Kekinian) dapat meningkatkan pendapatan ekonomi masyarakat desa Senyiur Kecamatan Keruak Kabupaten Lombok Timur. Uraian hasil dan pembahasan kegiatan PKM di lapangan dapat diuraikan sebagai berikut:

Sabut kelapa jika diurai akan menghasilkan serat sabut (cocofibre) dan serbuk sabut (cococoir).

\section{Hasil kegiatan}

1. Tercapainya Tujuan

Selama berlangsung PKM, Masyarakat antusias ikut berpartisipasi membuat Pot Bunga Kekinian (POBUKE) yang didampingi oleh tim PKM sampai berakhirnya kegiatan. Tahap demi tahap dilaksanakan dengan baik dan terstruktur berdasarkan arahan dari tim PKM. Mulai dari penguraian serabut kelapa. Serabut kelapa jika diurai akan menghasilkan serat sabut 


\section{ABSYARA: JURNAL PENGABDIAN PADA MASYARAKAT \\ BIDANG PENDIDIKAN, SAINS, DAN TEKNOLOGI}

Vol. 1 No. 1, Juli 2020, Hal. 33-43

e-ISSN: 2723-6269

(cocofibre) dan serbuk sabut (cococoir). Serabut kelapa yang akan diambil harus memiliki serat yang mempunyai karakteristik yang khas (Samosir,1992). Dari hasil observasi pada dasarnya masyarakat memiliki skill dalam mengolah limbah serabut kelapa dan mulai sadar tanaman kelapa dapat memberikan sumbangan yang besar bagi perekonomian rakyat dan Negara. (Warisno, 2003). Di bawah ini merupakan bagian dari tujuan capaian pot bunga kekinian berbasis geometri bersama masyarakat:
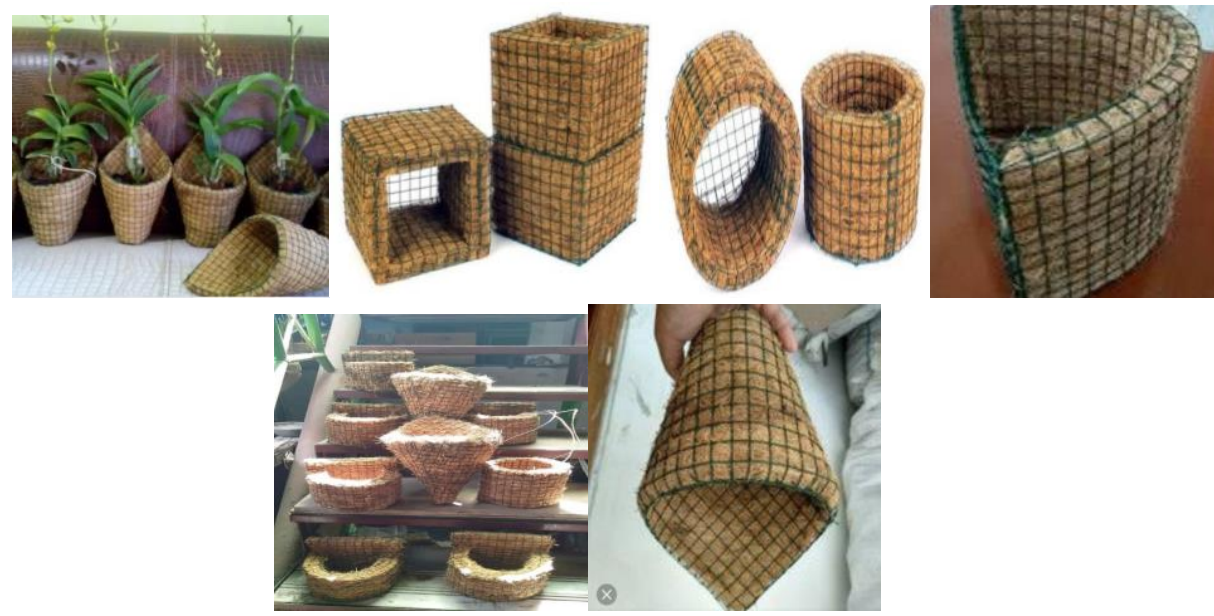

Gambar 4. Produk Pot Bunga Kekinian (POBUKE) Berbasis Geometri

2. Tercapainya Sasaran

Dalam kegiatan pengabdian masyarakat ini ada 2 sasaran

a. Sasaran objek yakni anak terlantar dan ibu rumah tangga.

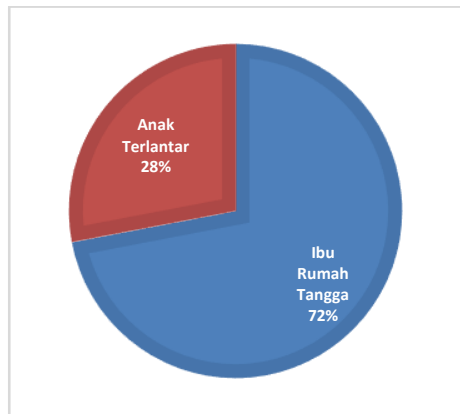

Gambar 5. Jumlah Capaian Sasaran Masyarakat Perajin POBUKE

b. Sasaran produksi. Sasaran produksi secara offline dan online. Secara offline melalui pemesanan langsung ke toko dan dipromosikan ke toko-toko. Secara online dengan memanfaatkan beberapa aplikasi media sosial seperti: WhatsApp, Facebook, messenger, Line, Twitter, serta aplikasi terupdete, adapun diagram jumlah capaian sasaran masyarakat yang digunakan sebagai berikut: 


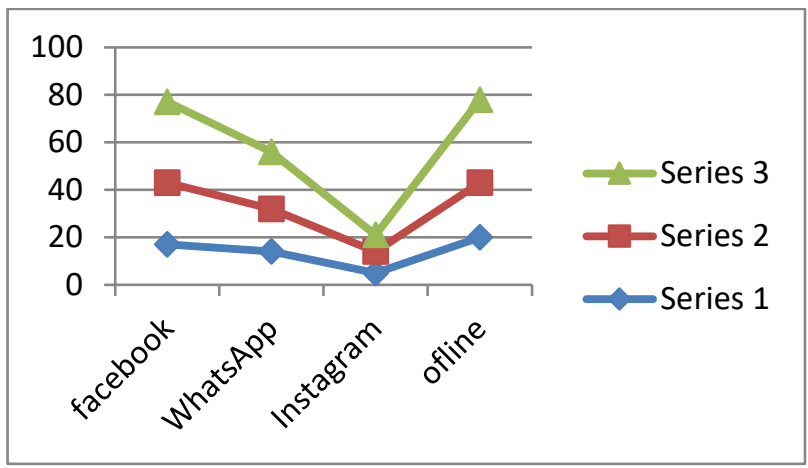

Gambar 6. Jumlah Capaian Sasaran Produksi berdasarkan pemasran secara online dan ofline

\section{Tercapainya Target}

Sesuai tujuan kegiatan PKM, yakni memanfaatkan limbah serabut kelapa menjadi pot kekinian (POBUKE) berbasis geometri. Adapun produk yang sudah dibuat dapat dilihat pada gambar dibawah ini:
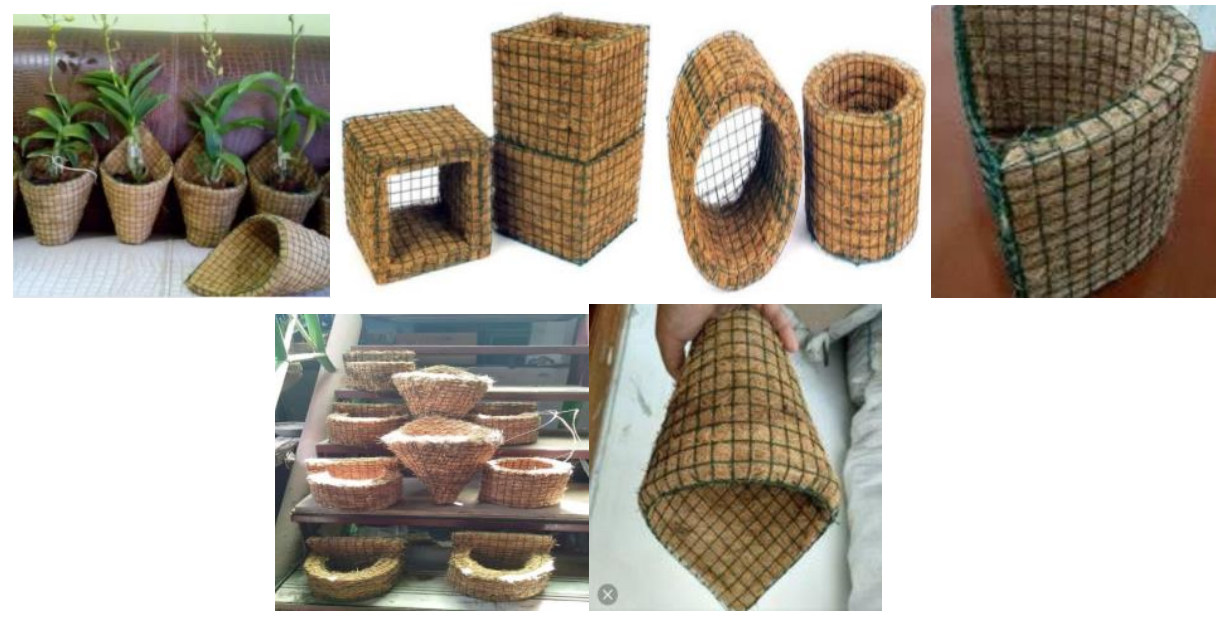

Gambar 7. Produk Pot Bunga Kekinian (POBUKE) Berbasis Geometri

4. Tercapainya Manfaat

Dengan adanya pembuatan pot kekinian (POBUKE) berbasis geometri tercapainya beberapa manfaat sebagai berikut

a. Limbah serabut kelapa mulai berkurang

b. Masyarakat pengangguran dan anak terlantar meiliki kegiatan yang membantu perekonomian dalam memenuhi kebutuhan sehari-hari

c. Terealisasinya program pemerintah dalam meminimalisir angka tingkat pengangguran, dan

d. Terealisasinya program pemerintah dalam memajukan desa tertinggal 


\section{SIMPULAN}

Pengabdian kepada masyarakat dalam hal ini adalah Pelatihan Pembuatan Pot Bunga Kekinian (POBUKE) berbasis geometri dari limbah sabut kelapa di Desa Senyiur, Kecamatan Keruak. Kabupaten Lombok Timur terlaksana sesuai rencana. Secara umum kegiatan berjalan sesuai dengan yang telah direncanakan. Dari bahan limbah sabut kelapa berhasil digunakan untuk pembuatan Pot Bunga Kekinian (POBUKE) berbasis geometri, dibuat dengan baik oleh anak terlantar dan ibu-ibu rumah tangga. Pelatihan pembuatan Pot Bunga Kekinian (POBUKE) berbasis geometri dari bahan limbah sabut kelapa yang telah dibuat desainnya menggunakan kawat jaring. Guna terwujudnya hasil yang maksimal tentu ada follow up dari kegiatan pelatihan ini, karena keberhasilan sebuah kegiatan pelatihan ini adalah adanya kesadaran dan keinginan dari anak terlantar dan ibu-ibu rumah tangga untuk mengaplikasikan serta mengembangkannya

\section{PERNYATAAN PENULIS}

Artikel ini belum pernah di publikasikan di jurnal manapun.

\section{DAFTAR PUSTAKA}

Agustian, A., Friyatno, S., Supadi, \& Askin, A. (2003). Analisis pengembangan agroindustri komoditas perkebunan rakyat (kopi dan kelapa) dalam mendukung peningkatan daya saing sektor pertanian. Makalah Seminar Hasil Penelitian Pusat Penelitian dan Pengembangan Sosial Ekonomi Pertanian Bogor. T.A. 2003. 38 hal

Allorerung, D., \& Lay, A. (1998). Kemungkinan pengembangan pengolahan buah kelapa secara terpadu skala pedesaan. Prosiding Konperensi Nasional Kelapa IV. Bandar Lampung 21 - 23 April 1998 Pp.327 - 340.

Anonim (2000). Hasil pengkajian sabut kelapa sebagai hasil samping. Jakarta: Bank Indonesia. hal 15.

APCC (2003). Coconut statistical yearbook 2002. Asia Pacific Coconut Community

Arifiandi , Yosha (2015). Penyuluhan Dan Pelatihan Pengolahan Sabut Kelapa . Jurnal Inovasi dan Kewirausahaan Volume 4 No. 2, Mei 2015

Aziz, Arrazak. (2018). Proposal Program Kreativitas Mahasiswa Sabut Kelapa Sebagai Bagnut (Polibag Coconut) Ramah lingkungan. Stikes Surya Mitra Husada Kediri

Nur, I. I., Kardiyono, U., \& Aris. A. (2003). Pemanfaatan limbah debu serabut kelapa dalam usaha tani padi pasang surut. Kelembagaan Perkelapaan di Era Otanomi Daerah. Prosiding Konferensi Nasional Kelapa V. Tembilahan, 22 - 24 Oktober 2002.

Pristi Suhendro Lukitoyo, dkk. (2019). Kaligrafi Sabut Kelapa.International jurnal of comunityservice learning, volume 3, no 2. 2019. Hal 51

Samosir, Y. (1992). Asal Usul Penyebaran Kelapa, dalam Kelapa (Cocos Nucifera)., Asosiasi Litbangbun, Puslitbun Marihat_Bandar Kuala Pematang Siantar. 


\section{ABSYARA: JURNAL PENGABDIAN PADA MASYARAKAT \\ BIDANG PENDIDIKAN, SAINS, DAN TEKNOLOGI}

Vol. 1 No. 1, Juli 2020, Hal. 33-43

e-ISSN: 2723-6269

Titi Indahyani. (2011). Pemanfaatan Limbah Sabut Kelapa Pada Perencanaan Interior Dan Furniture Yang Berdampak Pada Pemberdayaan Masyarakat Miskin. Jurnal HUMANIORA Vol.2 No.1: 15-23

Warisno. (2003).Budi Daya Kelapa Genjah.Yogyakarta:Penerbit Kanisius hal 9 